\title{
SOCIAL AND ENVIRONMENTAL REPORTING AND AUDITING IN INDONESIA Maintaining Organizational Legitimacy?
}

\author{
Anies S. Basalamah \\ Johnny Jermias*
}

The purpose of this study is to examine social and environmental reporting and auditing practices by companies in Indonesia. Consistent with our prediction, we found that social and environmental reporting and auditing are undertaken by management for strategic reasons, rather than on the basis of any perceived responsibilities. The results indicate that reporting and auditing social and environmental activities increases following threats to the company's legitimacy and ongoing survival. The results also support our prediction that social and environmental reports vary across companies.

This study calls for mandatory reporting and auditing of social and environmental activities through regulations and reinforcements. This mandatory requirement is particularly needed for companies with activities that are considered socially and environmentally sensitive. Furthermore, this study reveals that the social and environmental reporting and auditing are performed by organizations other than accounting profession. We propose that accountants should partake in these activities given the expertise that they could usefully bring to these areas.

Keywords: disclosures; environmental and social auditing; legitimacy theory

\footnotetext{
* Corresponding author: Both authors contributed equally to this study. The sequence of names was determined in random order. We gratefully acknowledge the constructive comments and suggestions from the anonymous reviewers of this journal.
} 
Gadjah Mada International Journal of Business, January-April 2005, Vol. 7, No. 1

\section{Introduction}

In recent years, there has been a substantial growth in social and environmental reporting and auditing, particularly by the business community. To some extend, this trend has been a response to stakeholder concerns about the social, environmental, and economic performance of the companies. This trend can be demonstrated by the increased number of guidelines provided by various government organizations, industry bodies, and accounting professions related to social and environmental disclosures. Most of the standards, however, are private and voluntary including governmentbased guidelines and regulations.

Despite its growing popularity, evidence suggests that information contained in the social and environmental reporting is rarely used by stakeholders and management to make business decisions (CSR Europe and Accountability 2002). There is a widely held belief that providing social and environmental disclosures has an adverse impact on the performance of companies. Friedman (1962), for example, argues that to maximize profit and therefore shareholder value, companies should just focus on performing tasks of generating profit legally and pay little attention to corporate social responsibility.

Some scholars have argued that since social and environmental disclosures are predominantly a voluntary practice, there is a need for mandatory regulations to reinforce this practice to preserve its existence (e.g., Gray 2002; $\mathrm{Neu}$ et al. 1998; Elkington 1997). Neu et al., (1998), found that companies voluntarily disclose social and environment issues in their annual reports only if these activities are perceived by management as important to manage public impressions of the companies' operations to establish or maintain the companies' legitimacy.

A number of reasons for managers to voluntarily disclose social and environmental information has been identified in the literature such as to comply with legal requirements (Deegan and Blomquist 2001), to gain competitive advantage by appearing as socially responsible (Hasnas 1998), to comply with borrowing requirements and community expectations (Deegan and Blomquist 2001), to manage powerful stakeholder groups (Ullman 1985), to legitimize various aspects of their respective organizations (Patten 1992), and to attract investment fund (Deegan and Blomquist 2001).

Because social and environmental reporting and auditing are predominantly a voluntary practice in most countries, there are no internationally agreed standards and their development is still in its infancy. It is not surprising, therefore, that there is still much debate and lack of consensus on key issues such as the objective reporting, the qualitative characteristics of the information, the users of the reports, and the proper presentation formats (Hedberg and Malmborg 2003). This lack of consensus, however, pro- 
vides great opportunities for research in this area.

Given that most of the guidelines and regulations are voluntary, social and environmental reports tend to be biased toward management's own interest. To assess the quality of a company's social and environmental performance, the reports should be audited by competent and independent parties. Watson and MacKay (2003) propose that the social and environmental audit should check a company's social and environmental performance against stated objectives and social and environmental policies. They further assert that the aims and objectives of the audit would be to check regularly and systematically, among other things, whether management systems are performing well, compliance with health and safety legislation, and the impact of the organization's activities on the environment and social well being.

The purpose of this study is, therefore, to investigate social and environmental reporting and auditing practices in Indonesia and to examine factors underlying management's motivation to disclose such information. Indonesia provides an interesting setting for studying this phenomenon given that there are a number of multi-national companies doing business in socially and environmentally sensitive areas such as logging, mining, and oil and gas. In addition, the government of Indonesia has recently issued parliamentary decree No. 23 in 1997 concerning the environmental manage- ment. This decree allows the Ministry of Environmental to require companies to report their social and environmental activities and to perform environmental and social audits.

As expected, the results indicate that the social and environmental reporting and auditing are undertaken by management for strategic reasons, rather than on the basis of any perceived responsibility. The activities are performed following threats to the companies' legitimacy and ongoing survival. In addition, we found that the formats and contents of social and environmental reporting and auditing reports vary across companies. Each company reports their social and environmental performance according to the request of management. Similarly, the items assessed in the audit reports are based on contracts agreed upon by management and the auditor. It is interesting to note that accountants are not involved in preparation and auditing of the social and environmental reports. This is surprising given the expertise that accountants could usefully contribute to these activities.

The remainder of the paper is organized as follows. The next section describes the theoretical background and the related literature. The third section analyses social and environmental reporting and auditing in Indonesia based on a sample of publicly available reports. The last section provides the conclusions and discussions of the main findings. 
Gadjah Mada International Journal of Business, January-April 2005, Vol. 7, No. 1

\section{Theoretical Background and Related Literature}

It is well documented in the accounting and business literature that social and environmental reporting and auditing are motivated by management's desire to legitimize various aspects of their company. These activities might be used by management when particular events occur that are perceived to be detrimental to the company's reputation and ongoing survival (e.g., Neu et al. 1998; Patten 1992). Gray et al. (1995) propose that companies may take certain actions to establish or to maintain legitimacy such as by educating society about changes in the company's actions, by altering how society perceives a company's actions without making changes to those actions, by attempting to divert society's attention away from the issues of concern to alternative issues, and by seeking to alter society's expectations of the company's actions. Their argument is consistent with the prescription of legitimacy theory.

Legitimacy theory prescribes that companies influence, and in turn be influenced by, the society in which they operate (Dowling and Pfeffer 1975). Lindblom (1994) defines legitimacy as a condition or status that exists when there is a fit between a company's value system and that of the society in which the company is a part. He further describes that the company's legitimacy is at risk when there is an actual or potential misfit between the two value systems.
Corporate disclosure policies represent ways by which management can influence society's perceptions about the companies. Guthrie and Parker (1990) argue that accounting disclosures serve as tools for constructing, sustaining, and legitimizing economic and political arrangements that contribute to the companies' private interests. Management will disclose information about social and environmental performance of the company if they perceive that the supply of that information is crucial for the survival of the company (Dowling and Pfeffer 1975). Management might also decide to collaborate with other parties that are considered to be legitimate (Fiedler and Deegan 2002). In a similar vein, DiMaggio and Powel (1983) assert that organizations will change their activities to conform to external expectations and to be legitimate. For example, because the majority of companies in an industry perform social and environmental reporting and auditing, there might be an institutional pressure on a company to also undertakes social and environmental reporting and auditing.

Empirical findings tend to support the predictions of legitimacy theory (e.g., Wilmshurst and Frost 2000; Deegan and Gordon 1996; Patten 1992). Using Australian data, Deegan and Gordon (1996) found that companies' social and environmental disclosure was positively related to the increase in threats from activities of social and environmental interest groups. Similarly, Patten (1992) found 
an increase in the North American oil companies' social and environmental disclosures following the Exxon Valdez oil spill that was considered a threat to the legitimacy of oil companies.

While legitimacy is considered to be a resource on which a company is dependent for survival (Dowling and Pfeffer 1975), it is also a resource that the company can manipulate for its own interest (Woodward et al. 2001). For example, a company might manipulate information provided to its stakeholders, particularly important stakeholders such as governments, creditors or social and environmental interest groups, to gain their support and approval or to distract their opposition and disapproval (Ullman 1985). This is because managers have an incentive to disclose information about their various social and environmental management programs and initiatives to the important stakeholders to indicate that they are conforming to the stakeholders' expectations. In such case, the information is disclosed for strategic reasons, rather than on the basis of perceived responsibility.

It is therefore paramount that the social and environmental disclosures should be audited by independent parties to ensure that the disclosures are objective and free from management's bias. At a broad level, social and environmental audits can be defined as a process that enables an organization to assess its social and environmental programs and activities in relation to society's requirements and expectations (Elkington 1997). Social and environmental audits might be undertaken for accountability purposes to try to explain the various social and environmental impacts of a company's activities. It might also be undertaken based on specific issues faced by the company such as the implications that might follow from opening or closing a particular plant.

Social and environmental reports can be used as a managerial device aimed to take away various pressure regarding social and environmental issues from the company (Watson and MacKay 2003). For example, PT Freeport Indonesia (PTFI) was criticized internationally for causing continuous sufferings of the habitat around the mining areas in West Papua. It is alleged that the company has destroyed the natural environment, social environment, culture, and other inhabitants (AMP-Demmak 2003). As part of the response, a social audit was performed by Labat-Anderson Incorporated (1997) while an environmental audit was conducted by Montgomery Watson Indonesia (1999) with the assistance of the American and Indonesian World Wildlife Fund.

Similarly, PT Inti Indorayon Utama (PTIIU) has been protested by North Sumatran's residents and various non-governmental organizations for their activities in Porsea (North Sumatra). The protesters claim that the company's activities have damaged the environment and social well being of people in Porsea. The company has also responded to these protests by undertaking environmental 
reporting and auditing performed by Labat-Anderson Incorporated (1996) in coordination with several non-government organizations interested in social and environmental issues, Ministry of Environment, and the Environmental Supervisory Board (BAPEDAL). The results of the social and environmental audits are provided separately (not part of the companies' annual reports).

From an economic perspective, managers may want to disclose information if the information will increase the company's value (Verecchia 1983). When information asymmetry between managers and investors exists (i.e., managers have access to information that investors do not), investors and creditors may assume the worst about the company and undervalue the company's stock or require a higher interest rate on loans in a condition of non-disclosure (Grossman 1981). Gibbins et al., (1990), argue that companies have an incentive to reduce information asymmetry when they rely on the capital markets to reduce perceived costs.

In contrast, managers may decide not to disclose information to protect proprietary information in order to exploit its potential economic benefits (Dye 1985). Cormier and Magnan (1997) argue that proprietary information may be used by third parties (e.g., employees, customers, suppliers, and competitors) to enhance their positions against the disclosing firm in contract negotiations or competitive situations. From a management per- spective, nondisclosure of proprietary information can result in lower third party costs. As proprietary information, social and environmental disclosures may represent significant costs to the firm when the information is publicly available (Cormier and Magnan 1997). By disclosing certain social and environmental costs such as social and environmental liabilities or commitments, companies might face a potential threat to their reputation. This disclosure might also affect their reported profit negatively.

The economic-based argument seems to be consistent with the practice of both PTFI and PTIIU. Their social and environmental reports and audits were not undertaken regularly and were not part of the companies' annual reports. The companies' unwillingness to disclose their social and environmental activities in their annual reports might indicate that management perceived the social and environmental information as risky and therefore might affect the company's value negatively (Cormier and Magnan 1997).

The preceding discussions indicate that social and environmental reporting and auditing tend to be voluntary and therefore lack of uniformity. Companies will choose to perform these activities to satisfy their important stakeholders such as government and social and environmental interest groups, and to establish or maintain the companies' legitimacy. In addition, companies operate in different industries might face different issues, 
and therefore might provide different reports. For comparability and consistency, however, social and environmental issues can be categorized into (1) physical and chemical impacts; (2) biological impacts; and (3) social, economical and cultural impacts (see for example Government Decree No. 27, 1999 regarding Analyses of Environmental Impact). Thus, it is possible that regardless of the variety of issues faced by different companies in different industries, comparable reports among companies might be produced. ${ }^{1}$

Given that there is no uniform standard for reporting and auditing social and environmental disclosures coupled with the fact that management can control the issues to be reported/ audited, we expect that there will be a significant variation in the contents and formats of social and environmental audits in Indonesia.

\section{Social and Environmental Reporting and Auditing in Indonesia}

Constitution No. 4 enacted in 1997 (amended by Constitution No. 23 of 1997) gives the Minister of Environment of the Republic of Indonesia an authority to order companies to undertake mandatory social and environmental reporting and auditing of their operations. Following this constitution, The Ministry of Environment issued decree No. 42 in 1994 which provides a guideline concerning the social and environmental reporting and auditing in Indonesia. In practice, however, most social and environmental reporting and auditing are voluntary and there is no uniform standard for these activities. Besides the Ministry of Environment's guidelines, most companies also use the ISO 14001 audit checklist or the partial audit standard developed by Hagler Bailly Indonesia (for pesticide industry) and Texaco (for oil and gas industry) as a reference.

For mandatory social and environmental audits, Minister of Environment in 2001 issued decree No. 30 as a guideline, and order environmental auditors to use the Indonesian $\mathrm{Na}$ tional Standard 19-14010-1997 and Indonesian National Standard 1914012-1997 issued by National Standardization Board (Badan Standardisasi Nasional or BSN) which are, surprisingly, almost a direct translation of the ISO 14010 and 14012 guidelines. Despite the Ministry of Environmental guidelines, social and environmental items to be audited remain unclear.

The case of PT Freeport

Indonesia (PTFI) and PT Inti Indorayon Utama (PTIIU) ${ }^{2}$

We use purposive sampling technique (Jaccard 1983) to select the re-

\footnotetext{
${ }^{1}$ In financial accounting and auditing, comparable and consistent financial statements and audit reports are generated by different companies in different industries.

${ }^{2}$ The reports and appendices are available publicly through the Ministry of Environment or upon request from the authors.
} 
ports to be reviewed in this study. We could not use random sampling technique due to the difficulty of determining the sampling frame (i.e., the list of companies that report and audit their social and environmental activities are not publicly available).

We review three reports for the purpose of this study: The 1999 external environmental audit report of P.T. Freeport Indonesia; The 1996 environmental, safety, and health audit of Pulp and Mill, Rayon Plant, and Forestry Operation of P.T. Inti Indorayon Utama; and The 1997 final social audit report of P.T. Freeport Indonesia. The reason for selecting these reports is that they are the only social and environmental reports publicly available. ${ }^{3}$ The reports are publicly available because the two companies were ordered by the Ministry of Environmental to undertake environmental audits due to complaints from local people and non-government environmental interest groups. For the social audit of PTFI, although it is a voluntary audit, the company makes this report publicly available and copies of this report can be obtained from the company.

\section{Format and content of the reports}

A general impression of the socalled social and environmental reporting and auditing released by the companies is that they are of very different standards (see Appendix 1), despite the fact that they have used the Ministry of Environment guidelines in some ways. Although the reporting and auditing of the environmental audits are mandatory, the audit scopes, which serve as the terms of reference, are determined by management. The following sections take a more specific look at the reports included in this study.

\section{Environmental reporting and auditing of PTFI}

PTFI called its environmental report as 1999 External Environmental Audit (Excluding Social, Cultural and Economic Impact) PT Freeport Indonesia Operations Irian Jaya, Indonesia (Montgomery Watson Indonesia 1999). The report begins with an executive summary consists of an overview, introduction, legislative framework and the company's environmental programs, significant issues and audit findings, and comments and recommendations. The main body consists of eight chapters. The first chapter provides information about the company's operating activities, audit scope based on the guidelines found in ISO 14010, 14011, and 14012, audit planning and process performed including a review of the company's environmental management, environmental resources and practices owned by the company, and the structure and content of the environmental report. It is interesting to note that this chapter

\footnotetext{
${ }^{3}$ Although interviews with managers and auditors might provide new insights into the reasons for conducting social and environmental activities by the companies, this study relies solely on analyzing publicly available documents due to time and budget constraints.
} 
also mentions about the names and expertise of each audit team member and external observers from the World Wildlife Fund (both from U.S. and Indonesia) and from Ministry of Mining and Energy.

The second and third chapters explain the company's environmental conditions and audit findings. It should be noted that the audit findings consist only of positive findings and therefore without any recommendations. Chapter four describes about international environmental management standards and a comparison with practices and programs of the company. Again, the conclusion is that the company's practices and programs are satisfactory with a recommendation that the company should maintain and update its existing practices and programs to keep up with the company's plan to change its mining operations in the future.

Chapters five, six, and seven describe how PTFI has satisfied the requirements of various Indonesian environmental rules and regulations and the progress made by the company regarding environmental issues identified in the previous year' report. The final chapter summarizes the major issues and recommendations for future actions.

\section{Environmental reporting and auditing of PTIIU}

PTIIU called its environmental report as Final Audit Findings: Environmental, Safety, and Health Audit of Pulp Mill, Rayon Plant, and Forestry Operations (Labat-Anderson In- corporated 1996). This report consists of an executive summary, four chapters and appendices.

The executive summary describes the reasons for environmental audit contract, the sequence of activities from the signed of the audit contract until the completion of the field work. This section also includes the members of the audit team (without mentioning their expertise), the term of reference (and changes made in it after discussions with non-government environmental interest groups, Ministry of Environment, and Environmental Supervisory Board) used to guide the audit work, an explanation of how the company perceives environmental reporting and auditing as important, and how the company attempts to improve their environmental management programs.

The first chapter, an introduction, summarizes the company's operating activities, audit scope, and sequence of activities beginning with a visit by the team to the plants in Porsea, and the name and affiliation of the audit team members, without any indication of their qualification. Chapter two and three explain, in more detail, the company's ongoing operations and its environmental management and monitoring activities. These chapters also contain comparisons between the company's environmental programs and those of the North-American companies.

Chapter four explains the social impacts of the company's activities. 
Gadjah Mada International Journal of Business, January-April 2005, Vol. 7, No. 1

This chapter also contains a letter from a non-government institution (Yayasan Bina Usaha Lingkungan) thanking the auditor for using the institution as a sub-contractor for conducting the audit. The appendices describe the stakeholders that received the reports, comparisons between the current audit findings and those of the previous year, social and environmental issues faced by the company, and follow-up actions related to audit findings and recommendations.

\section{Social reporting and auditing of PTFI}

PTFI called its social report as Final Social Audit Report PT Freeport Indonesia (Labat-Anderson Incorporated 1997). This report consists of an executive summary, three chapters, and appendices. The executive summary explains the social and political conditions surrounding the areas in which the company operates. This section also describes constraints and social conflicts that have emerged in the mining sites that have slowed down the community development program and efforts made to overcome these problems. The final part of this section described the progress made by the company in improving social condition such as the creation of Community Affair Department headed by a local people.

The first chapter describes the company's background, audit objectives, audit team, audit scope, and audit approaches and processes. This section also mentions that the social audit is performed under the supervision of Environmental Supervisory Board (Bapedal) and uses Ministry of Environmental decree No. 42 issued in 1994 as a guideline. Part of the audit work was outsourced to several institutions with an explanation that individuals from these institutions have expertise in sociology, anthropology, environmental observers, economic, agriculture and social development, doctor, community health, communication, educators and psychologist, management consultant, and people with long history of working and writing about West Papua. This team also includes three people from Papua that are affiliated with the local university (Labat-Anderson 1997).

The second chapter describes the audit findings, both negative and positive without any recommendations, and the company's important stakeholders which include PTFI, government, and local people. Chapter three discusses the findings reported in chapter two in more detail and provides recommendations. The report also mentions that some of the problems are very difficult and complicated and the company has not been able to solve them. There are three appendices attached to this report. Appendix A contains a list of individuals and organizations contacted during the activities. Appendix B explains the guideline used to develop the questionnaires employs by the team. Appendix C contains the interim report published in May, 1996. 
Basamalah \& Jermias - Social and Environmental Reporting and Auditing in Indonesia

\section{Reasons for Undertaking Social and Environmental Reporting and Auditing}

A general finding from the review of the three reports mentioned earlier is that the companies in this study were particularly interested in maintaining their legitimacy after some threats to their reputation and ongoing survival from local communities, environmental interest groups, and government agencies (both local and national). Both companies in our studies seem to have difficulties to convince their stakeholders that their operations are environmentally and socially acceptable. Because of the social and environmental problems related to their operations, both companies were ordered by the Ministry of Environment to undertake environmental reporting and auditing. In general, the ministry orders a company to report and audit their social and environmental activities only if there are evidences, among other things, that the company has jeopardized the social and environment of the surrounding areas in which it operates. ${ }^{4}$ As indicated earlier, the social audit of PTFI is a voluntary audit conducted by Labat-Anderson Incorporated (1997).

PTFI, for example, acknowledged that there is a huge perception gap between the company, government, and local people. The company al- leged that due to lack of expertise and human resources, Indonesian government cannot fulfill its obligation to provide satisfactory business environment for the company. Other issues such as Land rights, historical mistrust, and differences in leadership styles and values between local communities and those of the government and the company have caused various conflicts between the company and the local people. In 2001 PTFI was sued by Indonesian Forum for Environment (Wahana Lingkungan Hidup) for the pollution caused the company's operation in West Papua and the misleading information released by the company. Both the Southern Jakarta District Court and the Higher Court (Pengadilan Tinggi) ruled that the company violates the Constitution No. 23 of 1997 and ordered the company to fix its tailing system(s). The courts also mentioned that PTFI intentionally disguised certain information but published false and inaccurate information (dte.gn.apc.org 2001). The company, however, appealed to the Supreme Court and the case is still unsettled.

Similarly, PTIIU has been protested by local communities and various non-government organizations for several years. In a most recent protest, thousands of residents including activists from various non-government organizations, clergymen, and ulemas staged a protest against the reopening

\footnotetext{
${ }^{4}$ Constitution No. 23 of 1997 states that the Minister of Environment may order a company to undertake mandatory environmental audit when the company shows disobedience to the rules mentioned in this Constitution.
} 
of a suspended pulp plant in Toba Samosir regency, North Sumatra (Jakarta Post 2003). These protesters claimed that the company's operations have damaged the environment and the social value of people in Porsea, in particular and in North Sumatra, in general.

Both companies seem to face serious threats to their reputation and even ongoing survival. By reporting and auditing their social and environmental program and activities, they could gain a possibility to form a dialogue with their protesters and stakeholders. It is interesting to note that both companies collaborate with other parties that are considered to be legitimate in preparing their social and environmental reports (i.e., Ministry of Environment, Environmental Supervisory Board and Yayasan Bina Usaha Lingkungan for PTIIU; and World Wildlife Fund, Ministry of Mining and Energy of Indonesia, Several Indonesian Universities, and Science Institution of Indonesia for PTFI).

\section{Conclusions and Discussions}

This study investigates the practice and motivation for social and environmental reporting and auditing in Indonesia. The reports seem to be associated with significant threats faced by the company that might jeopardize their reputation and even their ongoing survival. Based on reviews of three reports by PT Freeport Indonesia and PT Inti Indorayon Utama, we also found that the format and contents of the reports vary significantly between the two companies. It is interesting to note that in all three reports, the audit scopes are determined by management of the companies. It is not surprising, therefore, that the tone of the reports and the findings tend to be positive and bias in favor of the company.

The findings are consistent with the prediction of the legitimacy theory. Fiedler and Deegan (2002), for example, propose that whenever managers consider that the supply of the particular information is crucial to organizational survival, they will exerts every effort to ensure that the information is available to the intended parties. They further assert that managers will also try to collaborate with other parties who are considered to be legitimate. In a similar vein, Guthrie and Parker (1990) argue that accounting disclosures are social, political, and economic tools. They serve as a means for constructing, sustaining, and legitimizing economic and political arrangements, institutions, and ideological themes which contribute to the company's private interests.

Woodward et al. (2001) propose that because managers tend to manipulate social and environmental disclosures for their own interest, it is crucial that the disclosures should be audited by independent parties and should be made mandatory, particularly for companies with activities that are considered socially and environmentally sensitive. Without mandatory requirement, management will 
only disclose social and environmental issues if they perceive that the benefits of disclosing such information outweigh the cost of producing and disclosing that information. The findings are also consistent with our prediction that the reports will be different between companies due to the lack of uniform standards for social and environmental reporting and auditing internationally, and particularly in Indonesia.

Furthermore, this study found that both the preparers and the auditors of the reports are controlled by the company and both the preparers and the auditors are from institutions other than accounting professions. It should be noted, however, that according to the Ministry of Environment Decree No. 12 issued in 1994, environmental auditor should have expertise in the process, procedures, and audit techniques, besides the technical knowledge in environmental field. Furthermore, the decree also requires that environmental auditors should have a good communication skill, be able to develop audit plan and time schedule, be able to analyze data and audit findings, and be able to write audit reports. A closer look at the format and content of the social and environmental reports presented in Appendix 1 reveals that they are very similar to those of financial(and particularlyoperational) audit reports prepared by accountants (a sample of operational audit report is presented in the fourth column of Appendix 1). Wilmshurst and Frost (2000) assert that accountants might contribute positively to environmental and social reporting and auditing because of their expertise in areas such as designing and implementing environment management system, conducting life cycle analyses, performing activity-based and cost benefit analyses, identifying important social and environmental issues and their impact on the company's operations, reporting the social and environmental activities of the company, and maintaining a good relationship with experts in social and environmental areas. We believe, therefore, that given the long historical practices of financial and operational audit reports with well established standards and procedures coupled with the expertise that accounting professional has regarding reporting and auditing business related issues, it would be beneficial to involve accounting professional in preparing and auditing social and environmental aspects of a company's activities. $^{5}$

The findings of this study, however, should be interpreted in light of two limitations. First, the reports re-

\footnotetext{
${ }^{5}$ It should be noted that financial audits can only be performed by certified public accountants. Other types of audits such as management, operational, and social and environmental audits, can be performed by experts other than certified public accountants. We believe, however, that with the reporting and auditing expertise that accounting professional has, professional accountants, together with other experts from related disciplines, will significantly improve the quality of social and environmental reports.
} 
Gadjah Mada International Journal of Business, January-April 2005, Vol. 7, No. 1

viewed in this study are not randomly selected and therefore caution should be taken in making inferences from the results of this study. Future research might extend this study by including more companies from different industries. Second, this study relies exclu- sively on publicly available information. Future studies might incorporate other approaches such as interviews with managers and auditors to gain more insights into the motivation to report and audit social and environmental activities.

\section{References}

AMP-Demmak. 2003. National Action Against PT Freeport Indonesia, Jakarta.

Cormier, D., and M. Magnan.1997. Corporate environmental disclosure strategies: determinants, costs, and benefits. Journal of Accounting, Auditing, and Finance 14 (4): 429-451.

CSR Europe and Accountability. 2002. Impacts of Reporting: The Roles of Social and Sustainability Reporting in Organizational Transformation. Brussels: CSR Europe and Accountability.

Deegan, C., and C. Blomquist. 2001. Stakeholder influence on corporate reporting: an exploration of the interaction between the World Wide Fund for nature and the Australian minerals industry. Paper presented at the Third Asian Pacific Interdisciplinary Research in Accounting Conference. Adelaide, Australia.

Deegan, C., and B.Gordon, (1996), A study of environmental disclosure practices of Australian corporations. Accounting and Business Research 26 (3): 187-199.

DiMaggio, P.J., and W.W. Powell. 1983. The iron cage revisited: institutional isomorphism and collective rationality in organizational fields. American Sociological Review 48: 147-160.

Dowling, J., and J.Pfeffer. 1975. Organizational legitimacy: social values and organizational behavior. Pacific Sociological Review: 122-126.

Down to Earth. 2001. Pengadilan memerintahkan Freeport untuk menyelesaikan masalahnya. Down to Earth 51 (November 2001). dte.gn.apc.org.

Dye, R. 1985. Disclosure of nonproprietary information. Journal of Accounting Research 23 (1): 123-145.

Elkington, J. 1997. Cannibals with Forks: The Triple Bottom Line of $21^{\text {st }}$ Century Business. Oxford: Capstone Publishing.

Fiedler, T., and C. Deegan. 2002. Environmental collaborations within the building and construction industry: A consideration of the motivations to collaborate. Paper Presented a at the Critical Perspectives on Accounting Conference. NY: New York.

Friedman, M. 1962. Capitalism and Freedom. Chicago, Illinois: University of Chicago.

Gibbins, M., A. Richardson, and J. Waterhouse. 1990. The management of corporate financial disclosures: opportunism, ritualism, policies, and process, Journal of Accounting Research 28 (1): 121-143. 
Basamalah \& Jermias - Social and Environmental Reporting and Auditing in Indonesia

Gray, R.H, R. Kouhy, and S. Lavers. 1995. Corporate social and environmental reporting: A review of the literature and a longitudinal study of UK disclosure. Accounting, Auditing, and Accountability Journal 8 (2): 47-77.

Gray, R. 2002. The social accounting project and accounting, organizations, and society privileging engagement, imaginings, new accounting and pragmatism over critique? Accounting, Organizations and Society 27 (7): 687-708.

Grossman, S. 1981. The informational role of warranties and private disclosure about product quality. Journal of Law and Economics 24 (3): 461-183.

Guthrie, J., and L.D. Parker. 1990. Corporate social disclosure practice: A comparative international analysis. Advances in Public Interest Accounting 3: 159-176.

Hagler Bailly Indonesia. 1999. Draft Panduan Audit Lingkungan Industri Pestisida. Jakarta: Hagler Bailly Indonesia.

Hasnas, J. 1998. The normative theories of business ethics: A guide for the perplexed. Business Ethics Quarterly 8 (1): 19-42.

Hedberg, C.J., and F.V. Malmborg. 2003. The global reporting initiative and corporate sustainability reporting in Swedish companies. Corporate Social Responsibility and Environmental Management 10 (3): 153-164.

Higgins, J. M. 1994. The Management Challenge: An Introduction to Management $\left(2^{\text {nd }}\right.$ Ed.). New York: Macmillan College Publishing Company.

Jaccard, J. 1983. Statistics for the Behavioral Sciences. California: Wadsworth Publishing Company.

Jakarta Post. 2003. Thousands Protest Pulp Plant “Operations" in Porsea, North Sumatra. Jakarta.

Labat-Anderson Incorporated. 1996. Final Audit Findings: Environmental, Safety, and Health Audit of Pulp Mill, Rayon Plant, and Forestry Operations. Jakarta: LabatAnderson Incorporated.

1997. Final Social Audit Report PT Freeport Indonesia. Jakarta: LabatAnderson Incorporated.

Linblom, C.K. 1994. The implications of organizational legitimacy for corporate social performance and disclosure. Paper presented the Critical Perspective on Accounting Conference. NY, New York.

Menteri Negara Lingkungan Hidup. 1994. Keputusan No. KEP-42/MENLH/11/1994 tentang Pedoman Umum Pelaksanaan Audit Lingkungan.

. 2001. Keputusan No. 30 Tahun 2001 tentang Pedoman Pelaksanaan Audit Lingkungan Hidup yang Diwajibkan Menteri Negara Lingkungan Hidup.

Montgomery Watson Indonesia. 1999. 1999 External Environmental Audit (Excluding Social, Cultural and Economic Impacts) PT Freeport Indonesia Operations irian Jaya, Indonesia. Jakarta: Montgomery Watson Indonesia.

Neu, D., H. Warsame, and K. Pedwell. 1998. Managing public impressions: Environmental disclosures in annual reports. Accounting, Organizations and Society 23 (3): 265-282. 
Gadjah Mada International Journal of Business, January-April 2005, Vol. 7, No. 1

Patten, D. 1992. Intra industry environmental disclosures in response to the Alaskan oil spill: a note on legitimacy theory. Accounting, Organizations and Society 17 (5): 471-475.

Republic of Indonesia. 1997. Constitution No. 23 on Environmental Management. Jakarta

Rosser, Ted. 1997. Auditing EMS: The ISO 14001 Audit Checklist. Heckmondwike, West Yorkshire, UK: Paramount Resources Limited.

Ullman, A.E. 1985. Data in search of a theory: A critical examination of the relationship among social performance, social disclosure and economic performance of US firms. Academy of Management Review 10 (3): 540-547.

Verecchia, R. 1983. Discretionary disclosure. Journal of Accounting and Economics 5 (3): 179-194

Watson, M., and J.MacKay. 2003. Auditing for the environment. Managerial Auditing Journal 18 (8): 625-630.

Wilmshurst, T.D., and G.R. Frost. 2000. Corporate environmental reporting: a test of legitimacy theory. Accounting, Auditing, and Accountability Journal 13 (1): 10-26.

Woodward, D., P. Edwards, and F. Birkin. 2001. Some evidence on executives' views of corporate social responsibility. British Accounting Review 33 (3): 357-397. 
Basamalah \& Jermias - Social and Environmental Reporting and Auditing in Indonesia

Appendix 1

Format and Content of the Social and Environmental Reporting and Auditing Reviewed in this Study (with a Comparison of an Operational Reporting and Auditing)

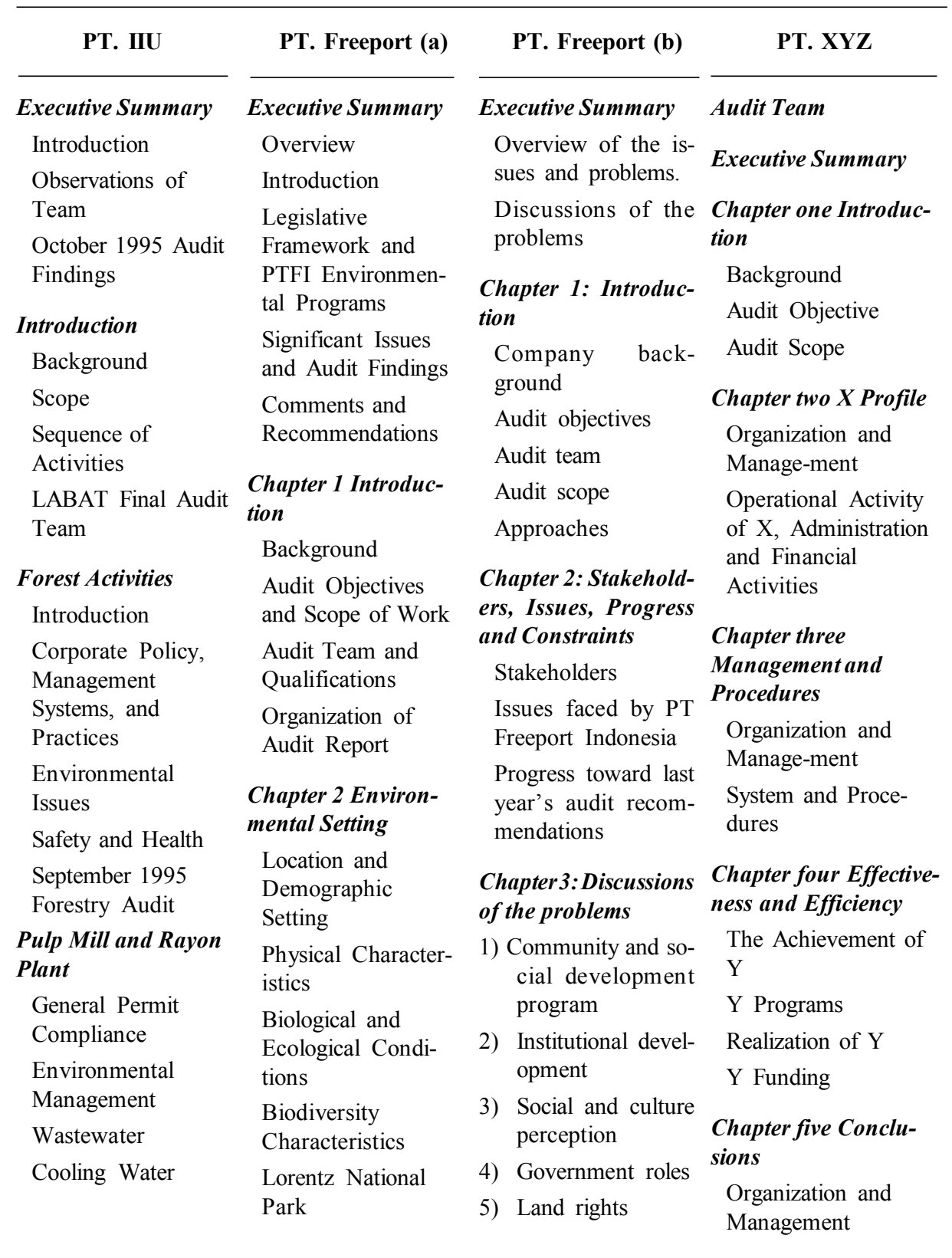


Gadjah Mada International Journal of Business, January-April 2005, Vol. 7, No. 1

\section{Continued from Appendix 1}

\begin{tabular}{|c|c|c|c|}
\hline PT. IIU & PT. Freeport (a) & PT. Freeport (b) & PT. XYZ \\
\hline \multirow{19}{*}{$\begin{array}{l}\text { Stormwater } \\
\text { Discharges } \\
\text { Air Emissions } \\
\text { Solid Water } \\
\text { Occupational Safety } \\
\text { and Health } \\
\text { Pollution Prevention } \\
\text { Community Relations } \\
\text { and Community } \\
\text { Development }\end{array}$} & \multirow{5}{*}{$\begin{array}{l}\text { Chapter } 3 \text { Waste and } \\
\text { Overburden } \\
\text { Management } \\
\text { Introduction } \\
\text { Tailings Manage- } \\
\text { ment Plan (Includ- } \\
\text { ing Acid Rock } \\
\text { Drainage) }\end{array}$} & $\begin{array}{l}\text { 6) Job opportunities } \\
\text { and training }\end{array}$ & $\begin{array}{l}\text { System and Proce- } \\
\text { dures }\end{array}$ \\
\hline & & 7) Education & \multirow{2}{*}{$\begin{array}{l}\text { Effectiveness and } \\
\text { Efficiency }\end{array}$} \\
\hline & & 8) Community health & \\
\hline & & $\begin{array}{l}\text { 9) Internal communi- } \\
\text { cations }\end{array}$ & \multirow[t]{16}{*}{ Appendices } \\
\hline & & 10) Public relations & \\
\hline & $\begin{array}{l}\text { Overburden } \\
\text { Management Plan } \\
\text { (Including Acid } \\
\text { Rock Drainage) }\end{array}$ & $\begin{array}{l}\text { 11) Communication } \\
\text { with stakeholders } \\
\text { 12) Company's prob- } \\
\text { lems }\end{array}$ & \\
\hline & $\begin{array}{l}\text { Solid and Hazard- } \\
\text { ous Waste Manage- } \\
\text { ment }\end{array}$ & \multirow[t]{13}{*}{ Appendices } & \\
\hline & $\begin{array}{l}\text { Liquid Waste } \\
\text { Management }\end{array}$ & & \\
\hline & $\begin{array}{l}\text { Chapter } 4 \text { Mine } \\
\text { Closure/Reclamation } \\
\text { Plan }\end{array}$ & & \\
\hline & Introduction & & \\
\hline & $\begin{array}{l}\text { Current PTFI } \\
\text { Practices }\end{array}$ & & \\
\hline & $\begin{array}{l}\text { Financial Assurance } \\
\text { Mechanism }\end{array}$ & & \\
\hline & Conclusions & & \\
\hline & $\begin{array}{l}\text { Chapter } 5 \text { Legislative } \\
\text { Setting and Compli- } \\
\text { ance }\end{array}$ & & \\
\hline & General Approach & & \\
\hline & $\begin{array}{l}\text { Framework for } \\
\text { Environmental } \\
\text { Management }\end{array}$ & & \\
\hline & $\begin{array}{l}\text { Chapter } 6 \text { PTFI } \\
\text { Environmental }\end{array}$ & & \\
\hline & $\begin{array}{l}\text { Management } \\
\text { Systems }\end{array}$ & & \\
\hline & Introduction & & \\
\hline
\end{tabular}


Basamalah \& Jermias - Social and Environmental Reporting and Auditing in Indonesia

\section{Continued from Appendix 1}

PT. IIU
PT. Freeport (a)

PT. Freeport (b)
PT. XYZ

\section{Environmental}

Policy

Environmental

Objectives and

Targets

Environmental

Organization and

Personnel

Environmental

Management

Manual

Environmental

Management

Reviews and Audits

Conformance and

Compliance

\section{Chapter 7 Environ- \\ mental Monitoring}

Water Quality

(Surface and

Ground Water)

Biological Monitor-

ing

Ambient Air

Quality

Flora and Fauna

Biodiversity

Other Monitoring

(Including Glacier)

Chapter 8 Conclu-

sions and Recom-

mendations

Chapter 9 References

Appendix 